\title{
Transatlantica
}

Revue d'études américaines. American Studies Journal

$1 \mid 2002$

Jeune République

\section{Don DeLillo : une bibliographie sélective}

\section{Aaron Smith}

\section{OpenEdition}

Journals

Édition électronique

URL : http://journals.openedition.org/transatlantica/523

DOI : 10.4000/transatlantica.523

ISSN : 1765-2766

Éditeur

AFEA

\section{Référence électronique}

Aaron Smith, «Don DeLillo : une bibliographie sélective », Transatlantica [En ligne], 1 | 2002, mis en ligne le 23 mars 2006, consulté le 29 avril 2021. URL : http://journals.openedition.org/transatlantica/ 523 ; DOI : https://doi.org/10.4000/transatlantica.523

Ce document a été généré automatiquement le 29 avril 2021

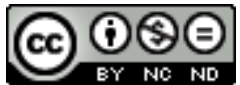

Transatlantica - Revue d'études américaines est mis à disposition selon les termes de la licence Creative Commons Attribution - Pas d'Utilisation Commerciale - Pas de Modification 4.0 International. 


\section{Don DeLillo : une bibliographie sélective}

\section{Aaron Smith}

Oeuvres de Don DeLilloRomans

Americana. 1971. London : Penguin, 1990.

End Zone. 1972. New York : Penguin, 1986.

Great Jones Street. 1973. New York : Penguin, 1994.

Ratner's Star. 1976. London : Vintage, 1991.

Players. 1977. London : Vintage, 1991.

Running Dog. 1978. London : Picador, 1992.

7 The Names. 1982. New York : Vintage, 1989.

8 White Noise. 1984. London : Picador, 1985.

9 Libra. 1988. London: Penguin, 1989.

10 Mao II. 1991. London : Vintage, 1992.

11 Underworld. 1997. New York : Scribner, 1997.

12 The Body Artist. 2001. New York: Picador, 2001.

13 Cosmopolis. New York : Scribner, 2003 (à paraître)

Théâtre

14 The Engineer of Moonlight. Cornell Review 1 (1979) : 21-47.

15 The Day Room. 1986. New York : Penguin, 1989.

16 The Rapture of the Athlete Assumed into Heaven. The Quarterly 15 (1990).

17 Valparaiso. New York : Scribner, 1999.

Nouvelles

18 « Baader-Meinhof ». New Yorker 1 April 2002 : 78-82

19 «Baghdad Towers West ». Epoch 17 (1968) : 195-217.

20 «Coming Sun. Mon. Tues. ». Kenyon Review 28 (1966) : 391-394. 
«Creation ». Antaeus 33 (1979) : 32-46.

« Human Moments in World War III ». Esquire July 1983 : 118-26.

«In the Men's Room of the Sixteenth Century ». Esquire Dec. 1971 : 174-77, 243, 246.

«Pafko at the Wall ». Harper's Magazine Oct. 1992 : 35-70.

«Spaghetti and Meatballs ». Epoch 14 (1965) : 244-250.

« Take the 'A' Train ». Epoch 12 (1962) : 9-25.

«The Angel Esmeralda ». Esquire May 1994 : 100-109.

«The Black-and-White Ball ». The New Yorker January 1997 : 80-89.

« The Ivory Acrobat ». Granta 25 (Autumn 1988): 199-212.

« The River Jordan ». Epoch 10 (1960): 105-20.

« The Runner ». Harper's Magazine September 1988 : 61-63.

« The Uniforms ». Carolina Quarterly 22 (1970): 4-11.

Essais

« American Blood: A Journey through the Labyrinth of Dallas and JFK ». Rolling Stone 8 Dec. $1983: 21-2,24,27-8,74$.

« The Power of History ». New York Times Magazine 7 Sept. 1997 : 60-63.

«In the Ruins of the Future: Reflections on terror and loss in the shadow of September ». Harper's Dec. 2001 : 33-40.

Études sur DeLilloOuvrages consacrés à DeLillo

Brooks, Carlo. «La préemption de l'image dans les romans de Don DeLillo ». (Thèse) Université de Pau, 1999.

Cowart, David. Don DeLillo : The Physics of Language. Athens : University of Georgia Press, 2002.

Happe, François. Don DeLillo : La fiction contre les systèmes. Paris : Belin, 2000.

Happe, François. «Ecriture et pouvoir dans les romans de Don DeLillo ». (Thèse) Université d'Orléans, 1998.

Keesey, Douglas. Don DeLillo. New York : Twayne, 1993.

LeClair, Tom. In the Loop : Don DeLillo and the Systems Novel. Chicago : University of Illinois Press, 1987.

Lentriccia, Frank (ed). Introducing Don DeLillo. Durham : Duke University Press, 1991.

Osteen, Mark. American Magic and Dread. Philadelphia : University of Pennsylvania Press, 2000 .

4 Smith, Aaron. «Primal Joy / Primitive Control : les phénomènes énumératifs dans les romans de Don DeLillo. » (Thèse) Université de Pau et Pays de l'Adour, 2002.

Tréguer, Florian. « Représentation critique et statut du signe dans l'oeuvre romanesque de Don DeLillo. » (Thèse) Université de Rennes II, 1999.

Entretiens et profils

Begley, Adam. «Don DeLillo: The Art of Fiction CXXXV ». Paris Review 128 (1993): 274-306.

Chénetier, Marc et François Happe. «An Interview with Don DeLillo ». Revue françasie des études américaines Janvier 2001 : 102-111. 
DeCurtis, Anthony. "'An Outsider in This Society' : An Interview with Don DeLillo ». Introducing Don DeLillo. Ed. Frank Lentricchia. Durham and London : Duke University Press, 1991 : 43-66.

Harris, Robert R. « A Talk with Don DeLillo ». New York Times Book Review 10 Oct. 1982 : 26.

LeClair, Thomas. « An Interview with Don DeLillo ». Anything Can Happen : Interviews with Contemporary American Novelists. Eds by Thomas LeClair and Larry McCaffery. Urbana : University of Illinois Press, 1983. 79-90.

Nadotti, Maria. «An Interview with Don DeLillo ». Translated by Peggy Boyers. Edited by Don DeLillo. Salmagundi Fall 1993 : 86-97.

Osen, Diane. «A Conversation with Don DeLillo ». The BOMC Reading Room. Book of the Month Club. 24 juillet 1997. Online. http://209.67.253.214/NBF/docs/ wwl_curri_DeLillo.htm

Passaro, Vince. « Dangerous Don DeLillo ». New York Times 19 May 1991 : Sec. 6, 34-36, 38, 76-77.

Remnick, David. « Exile on Main Street ». New Yorker 15 Sept. 1997 : 42-48.

Williams, Richard. « Everything Under the Bomb ». The Guardian 10 Jan. 1998.

Articles ou chapitres d'ouvrages

Allen, Glen Scott. «Raids on the Conscious: Pynchon's Legacy of Paranoia and the Terrorism of Uncertainty in Don DeLillo's Ratner's Star ». Postmodern Culture Vol. 4, \#2 (1994).

Baker, Peter. "The Terrorist as Interpreter: Mao II in Postmodern Context». Postmodern Culture, Vol. 4, \#2 (1994).

Bawer, Bruce. « Don DeLillo's America ». New Criterion April 1985 : 34-42.

Bernstein, Stephen. "Libra and the Historical Sublime ». Postmodern Culture Vol. 4, \#2 (1994).

Bonca, Cornel. " Don DeLillo's White Noise: The Natural Language of the Species ». College Literature, Vol. 23, \#2 (1996) : 25-44.

Brooks, Carlo. « Désespoir et possibilité : le problème de l'appartenance au monde dans Moon Palace et Libra » QWERTY n 6 (1996) : 163-175.

Brooks, Carlo. « Paroles claires et figures brouillées : la nomination dans The Names de Don DeLillo». Vagues Figures: les promesses du flou. ed. Bertrand Rougé. Pau: Publications de l'Université de Pau, 1997.

Bryant, Paula. «Discussing the Untellable : Don DeLillo's The Names ». Critique 29.1 (1997) : 16-29.

Bryson, Norman. « City of Dis : The Fiction of Don DeLillo ». Granta 2 (1980) : 145-57.

Burke, William. « Football, Literature, Culture. » Southwest Review 60 (1975) : 391-98.

Cain, William E. «Making Meaningful Words: Self and History in Libra». Michigan Quarterly Review Vol. 29 (1990) : 275-87.

Carmichael, Thomas. «Lee Harvey Oswald and the Postmodern Subject: History and Intertexuality in Don DeLillo's Libra, The Names and Mao II ». Contemporary Literature (Summer 1993) : 204-218. 

and Running Dog ». Powerless Fictions? Ethics, Cultural Critique, and American Fiction in the Age of Postmodernism. Ed. Ricard Miguel Alfonso. Amsterdam \& Atlanta: Rodopi, 1996. 113-39.

Chauvin, Serge. «L'œil des foules; DeLillo, Mao, la photo ». dans Marie-D. Garnier (Ed.) Jardins d'hiver. Littérature et photographie. Paris : Presses de l'Ecole Normale Supérieure, 1997. 187-189.

Chénetier, Marc. « DeLillo, la résistance aux systèmes ». Le Monde 29 juillet 1994 : 16.

Cordesse, Gérard. «Bruits et paradoxes dans White Noise de Don DeLillo». Revue Française d'Etudes Américaines, n 76 (1998) : 54-62.

Couturier, Maurice. «L'histoire et la refiguration de l'instant: White Noise de Don DeLillo. » Revue Française d'Etudes Américaines nº 62 (1994) : 382-392.

Cowart, David. «For Whom the Bell Tolls : Don DeLillo's Americana ». Contemporary Literature Vol. 37, \#4 (1996) : 602-19.

Edmundson, Mark. « Not Flat, Not Round, Not There : Don DeLillo's Novel Characters ». Yale Review (April 1995) : 107-124.

Happe, François. «La conspiration du hasard: histoire et fiction dans Libra de Don DeLillo ». Revue Française d'Etudes Americaines n 68, (1996) : 98-107.

Happe, François. «L'Amérique de Don DeLillo, ou l'Empire des Signes ». Europe 733 (1990) : 55-58.

Happe, François. «Voix et Autorité dans End Zone de Don DeLillo ». Revue Française d'Etudes Américaines n 54 (1992) : 385-394.

Johnston, John. «Generic Difficulties in the Novels of Don DeLillo ». Critique (Summer 1989) : 261-275.

Kucich, John. «Postmodern Politics : Don DeLillo and the Plight of the White Male Writer ». Michigan Quarterly Review 27.2 (1988) : 328-41.

LeClair, Thomas. « Post-Modern Mastery ». Delta (1983) : 99-111.

LeClair, Tom. « Missing Writers ». Horizon Oct. 1981 : 48-52.

Lish, Gordan. « Afterword ». Cornell Review 1 (1979) : 48-49.

Lish, Gordan. « What I Know about Don DeLillo and Certain Other Unnamed Persons ». Saturday Review 19 Sept., 1978 : 39-41.

3 Malby, Paul. «The Romantic Metaphysics of Don DeLillo ». Contemporary Literature 37.2 (1996) : 258-77.

Mullen, Bill. « No There There : Cultural Criticism as Lost Object in Don DeLillo's Players

O’Donnell, Patrick. « Obvious Paranoia: The Politics of Don DeLillo's Running Dog ». Centennial Review 34.1 (1990) : 56-72.

Osteen, Mark. "Children of Godard and Coca-Cola : Cinema and Consumerism in Don DeLillo's Early Fiction ». Contemporary Literature 37.3 (1996) : 439-70.

7 Pellegrin, Jean-Yves. «Le désordre du discours dans End Zone de Don DeLillo ». Revue Française d'Etudes Américaines, nº 76 (1998) : 63-72.

8 Rafferty, Terrence. « Self-Watcher ». The New Yorker, 26 September 1988.

Saltman, Arthur M. « The Figure in the Static: White Noise ». Modern Fiction Studies, 40.4 (1994) : 807. 
90 Scanlan, Margaret. «The Writer Among Terrorists: Don DeLillo's Mao II and the Rushdie Affair ». Modern Fiction Studies 40.2 (1994) : 229-252.

91 Smith, Aaron. "Lire les listes de DeLillo ». Profils américains, hiver 2002. (à paraître)

92 Zinman, Toby Silverman. " Gone Fission : The Holocaustic Wit of Don DeLillo ». Modern Drama 34.1 (1991) : 74-87. 